\title{
ANALYSIS OF HOSPITAL INFORMATION MANAGEMENT SYSTEM USING HUMAN ORGANIZATION FIT MODEL
}

\author{
Analisis Sistem Informasi Manajemen Rumah Sakit dengan \\ Human Organization Fit Model \\ Husnaina Febrita ${ }^{1}$, Martunis $^{2}$, ${ }^{*}$ Dedy Syahrizal ${ }^{1}$, Munifah Abdat ${ }^{3}$, Bakhtiar ${ }^{4}$ \\ ${ }^{1}$ Faculty of Medicine, Syiah Kuala University, Banda Aceh, Indonesia \\ ${ }^{2}$ Aceh Health Training Center, Aceh Health Department, Banda Aceh, Indonesia \\ ${ }^{3}$ Faculty of Dentistry, Syiah Kuala University, Banda Aceh, Indonesia \\ ${ }^{4}$ Department of Pediatrics, Faculty of Medicine, Syiah Kuala University, Banda Aceh, Indonesia \\ *Correspondence: dedysyahrizal@unsyiah.ac.id
}

\begin{abstract}
Background: Hospital is a health care institution that provides public services for patients. It needs computerized information technology, for example, a hospital information management system.

Aims: This study was aimed at analyzing the implementation of hospital management information system using the human organization fit model at the Outpatient Department of Sabang General Hospital.

Methods: This study was conducted from March-June 2020 using a cross sectional design. The study's population was the hospital managers, administration staff and health workers at the hospital. The study's sample size was 106 respondents selected using a purposive sampling. This study used a quantitative design in which the data analysis was done using a spearman correlation test with P-value of $=<0.05$. The independent variables were the quality of system, quality of information, and quality of care. While the dependent variables included system user, user satisfaction and organization. The data were collected through questionnaire distributed to the respondents.

Results: The quality of system did not have a relationship with the system user $(P=0.585)$, user satisfaction $(P=0.541)$, and organization $(P=0.256)$. The quality of information had a relationship with the system user $(P=0.004)$ and user satisfaction $(P=0.000)$, but it did not have a relationship with organization $(P=0.132)$. The quality of care had a relationship with the system user $(P=0.000)$, user satisfaction $(P=0.000)$ and organization $(\mathrm{P}=0.000)$.

Conclusion: The Sabang General Hospital, Aceh, needs to improve the hospital management information system with the HOT-fit model, especially the quality of system. They can conduct training for users and provide applicable and attractive manuals.
\end{abstract}

Keywords: hospital, information management system, quality of care, quality of information, quality of system.

\section{ABSTRAK}

Latar Belakang: Rumah sakit merupakan institusi pelayanan kesehatan kepada pasien. Hal ini menuntut rumah sakit untuk menerapkan teknologi informasi berbasis computer seperti Sistem Manajemen Informasi Rumah Sakit.

Tujuan: Penelitian ini bertujuan untuk menganalisa penerapan dari Sistem Manajemen Informasi Rumah Sakit yang menggunakan human organization fit model di Instalasi Rawat Jalan Rumah Sakit Umum Daerah Sabang. Metode: Penelitian ini dilakukan pada bulan Maret-Juni 2020 dengan desain cross sectional. Populasi penelitian ini adalah manajer rumah sakit, staf administrasi dan petugas kesehatan. Sampel dalam penelitian berjumlah 106 responden yang didapatkan melalui purposive sampling. Desain penelitian ini adalah kuantitatif dimana data dianalisis menggunakan korelasi spearman dengan skala ukur didasarkan pada nilai $p=<0.05$. Variabel independen dalam penelitian ini adalah kualitas sistem, kualitas informasi, kualitas pelayanan. Variabel dependen dari penelitian ini adalah sistem pengguna, kepuasan pengguna dan organisasi. Data dikumpulkan menggunakan kuesioner yang didistribusikan kepada responden.

Hasil: Kualitas sistem tidak berhubungan dengan sistem pengguna $(p=0.585)$, kepuasan pengguna $(p=0.541)$, dan organisasi $(p=0.256)$. Kualitas informasi berhubungan dengan sistem pengguna $(p=0.004)$ dan kepuasan pengguna $(p=0.000)$, dan tidak berhubungan dengan organisasi $(p=0.132)$. Kualitas perawatan berhubungan dengan sistem pengguna $(p=0.000)$, kepuasan pengguna $(p=0.000)$ dan organisasi $(p=0.000)$.

Kesimpulan: Penerapan dari Sistem Manajemen Informasi Rumah Sakit dengan Model HOT-fit di rumah sakit umum daerah Sabang, Aceh perlu ditingkatkan khususnya terkait kualitas system yang tersedia. Perbaikan kualitas sistem dapat diperbaiki melalui pelatihan kepada pengguna dan menyediakan sistem yang aplikatif dan menarik bagi para pengguna sistem. 
Kata kunci: Rumah Sakit, Sistem Informasi Manajemen, Kualitas Sistem, Kualitas Informasi, Kualitas Pelayanan

\section{INTRODUCTION}

Health and information technology is growing rapidly. Currently, the field of health relies greatly on the development of information technology for fast and precise services provided to the community (Saputra, 2016). The information of technology can improve types of businesses, increase the efficiency and effectiveness of business processes, and make management decisions and work groups for health service providers that can be competitive in an ever-changing market later (Rusdiana, 2014). A study has shown that information management system can reduce the error rates, increase the quality system (Agustina and Susilani, 2018) and reduce diagnostic errors (El-Kareh, Hasan and Schiff, 2013). Alotaibi and Federico (2017) assert that an electronic medical record reduces medical errors and improves patient safety.

Hospitals are agencies providing public services that require a good information management system. This system has become a necessity and demand for hospitals to implement a computerized information and communication technology, known as hospital information management system. This system is also a perequisite from the government to to improve the hospital performance, efficiency, effectiveness, professionality, and services. The system implementation is common for all hospitals in Indonesia (Peraturan Menteri Kesehatan, 2013).

With the hospital information management system, hospitals could manage complicated problems, such as medical records and other administrative data (Sudiarti, Soepangat and Wiyono, 2019). It is necessary to evaluate the implemented system to determine aspects that improve the use of the system. Hospitals can develop this system by considering user needs and factors affecting the user and its benefits that the user obtains (Agustina and Susilani, 2018). The evaluation of the information technology must comprehensively involve to the hospital (Erimalata, 2016). The evaluation of quality of the ongoing information system is necessary to determine to which exent it provides services and gain user's perspective of their convenience and satisfaction with the system (Nofikasari and Sunyoto, 2017). The health information system could improve the patient care and reduce medication errors, as well as support clinical decisions effectively (Farzandipou et al., 2017).

The Human Organization Fit Model proposed by Yusof et al. (2006) is one of the theoretical frameworks to evaluate information systems in the field of health services. It places the most important components in the information system: humans, organizations, technology and the compliance of those components (Diantono and Winarno, 2018). The information system considers some factors, such as the user, the frequency of use, training for the user, user's experience, knowledge, expectations, and attitudes towards the system. The user satisfaction is the overall evaluation of user's experience and social impact in using information systems (Ayuardini and Ridwan, 2019). The organizational component views the system from the organizational structure and environment. Besides, planning, management, system control, management support, financing and technology components are evaluated from the system quality, information 
quality and service quality (Poluan, Lumenta and Sinsuw, 2015).

Larinse (2015) and Saputra (2016) have discovered the quality of the system was not related to user satisfaction. Good user satisfaction and quality system do not indicate any problems in terms of human resource variable. Especially, human resources with high education levels and work experience may perform a high level of motivation and productivity (Diantono and Winarno, 2018). The hospital information management system is prominent for the hospital development. Without integrated, comprehensive, up-todate and sustainable data, it is impossible to improve, prepare and consider a large amount of funds to improve the efficiency and effectiveness of hospital services (Saputra, 2016). An evaluation is necessary to identify the implementation of the hospital information management system as a reference for policy making from the user's perspective. Based on the background, this study aimed to analyze a hospital information management system using the human organization fit (HOT-fit) model at Sabang General Hospital, Aceh.

\section{METHOD}

This study was conducted in MarchJune 2020 with a quantitative design and cross-sectional approach. The population of this study was the hospital manager, administration staff and health workers in the General Hospital of Sabang, Aceh. The initial number of the respondents were 114 people, but 8 people could not be interviewed did not return the questionnaire distributed by the researchers. The final study's sample size was 106 respondents selected using a purposive sampling technique which took some criteria for the selected repsondents to be more representative.

The analysis indicator was that $\mathrm{P}$ value should be equal or less than 0.05 .
There were three stages of data analysis: descriptive/univariate analysis and bivariate analysis. The univariate stage described variables, and the bivariate analysis using a spearman correlation test identified the relationship between variables (Dahlan, 2017). The dependent variables included the quality of system, quality of information, and quality of care. The quality of system was the user's subjective assessment on the system functions and implementation at the hospital. The indicators of this variable were its navigation, time to respond, the functions and availability of features, system reliability, completeness of the features, system flexibility, and system security. This variable was evaluated from some indicators: information completeness, accuracy, easy to read, punctuality, relevance, and consistency or clarity. The quality of care was the user' assessment on the services requested and received from the hospital information management. Its indicators included provider's responsiveness, guarantee, empathy, and technical support.

In addition, the study's dependent variables were the system user, user satisfaction, and organization. The system user was the frequency of using the information management system app. This variable's indicators involved navigation, user's needs and desires. The user satisfaction was a subjective response to the user's experience in using the information management system app. The variable's indicators varied from system completeness, accuracy, format, easy navigation and system accuracy. Another dependent variable was organization which was assessed from the hospital management aspect. App maintenance, employer commitment, and teamwork procedures were the indicators of organization variable. 
This study obtained data through questionnaire distributed to the respondents. Before conducting the research, the ethical approval was given by the Ethics Committee of Health Research, Faculty of Medicine, Syiah Kuala University, District General Hospital of Zainoel Abidin Banda Aceh.

\section{RESULTS AND DISCUSSION Respondents' Characteristics}

There are four respondents' characteristics investigated in this study: gender, age, education level and type of work in the hospital structure.

Table 1. Respondents' Characteristics

\begin{tabular}{lcc}
\hline \multicolumn{1}{c}{ Characteristics } & $\mathbf{n = 1 0 6}$ & $\mathbf{\%}$ \\
\hline Gender & & \\
- Male & 23 & 21.7 \\
- Female & 83 & 78.3 \\
\hline Age & 26 & 24.5 \\
- 20-30 & 49 & 46.2 \\
- 31-40 & 28 & 26.4 \\
- 41-50 & 3 & 2.8 \\
- 50-60 & & \\
\hline Education Level & & 10.3 \\
- Specialist doctor & 11 & 0.9 \\
- Master degree & 1 & 32.1 \\
- Bachelor degree & 34 & 56.6 \\
- Associate degree & 60 & \\
\hline Type of work & & \\
- Management staff & 15 & 14.2 \\
- Health staff & 87 & 82 \\
- Insurance staff & 4 & 3.8 \\
\hline Source: Primary data & &
\end{tabular}

The number of female respondents $(78.3 \%)$ was more dominant than males $(21.7 \%)$. Most of the respondents were at the age of $31-40$ years $(46.2 \%)$ and had Associate degree (56.6\%). The respondents participating in this study were mostly health staff $(82 \%)$.

\section{Analysis of Hospital Management Information System Using HOT-Fit Model}

A information management system is an integrated system providing information to support the operational activities, management and decision making of an organization. It is also an output resulted from the input of information from various processes to meet certain objectives in the management activities. The hospital's information system can influence the quality of care if properly repaired. Whether the system works well or not depends on the quality of information and types of services offered. An information management system app can support patient care and administration process in a relevant and accessible use, as well as flexible format that people in different locations can access. Service transaction data are collected, stored, processed, and documented to generate information about the quality of patient care and the hospital's service performance and costs.

The HOT-Fit model is the development of SI DeLone and McLean's success model by adding organizational factors and dimensions: structure and environment; technological, human and organizational factors, two ways of relationship between information quality and system use, information quality and user satisfaction, structure and environment, structure and net benefit, and environment and net benefit (Pamugar, Winarno and Najib, 2014). This study found that there are some meaningful use of the information management system. According to Ingebrigtsen et al., (2014), the application of information management system can be a capture key patient health information, clinical decision support, facilitate reporting the quality of measures to inform quality improvement efforts and to facilitate cost of care. The system user can be assessed from the effects of work, efficiency and effectiveness of the system, communication, and low error rates by controlling expenses and costs. "Fit" is measured and analyzed using three factors, such as human, organization, and technology.

\section{Univariate Analysis}

Univariate analysis tests a single variable to identify the characteristics of the variable. 
The study shows that a half of the respondents thought the quality of the system was lacking (52.8\%), and more than a half mentioned the quality of information given was good. The quality of the service was good according to most of the respondents $(61.3 \%)$ in this study. Around 50 respondents (67.9\%) considered the hospital has a good system user while 50 respondents $(67.9 \%)$ felt dissatisfied with the system. Additionally, a half of the respondents $(51.9 \%)$ thought the organization of the system was good.

Table 2. Univariate Analysis

\begin{tabular}{lcc}
\hline \multicolumn{1}{c}{ Variable } & $\mathbf{n = 1 0 6}$ & $\%$ \\
\hline $\begin{array}{l}\text { Quality of system } \\
\text { - Poor }\end{array}$ & 56 & 52.8 \\
- Good & 50 & 47.2 \\
\hline $\begin{array}{l}\text { Quality of } \\
\text { information }\end{array}$ & & \\
- Poor & & \\
- Good & 46 & 43.3 \\
\hline Quality of care & 60 & 56.6 \\
- Poor & & \\
- Good & 41 & 38.7 \\
System user & 65 & 61.3 \\
- Poor & & \\
- Good & 50 & 47.2 \\
\hline User Satisfaction & 56 & 52.8 \\
- Poor & & \\
- Good & 50 & 47.2 \\
\hline Organization & 56 & 52.8 \\
- Poor & & \\
- Good & 51 & 48.1 \\
Source: Primary data & 55 & 51.9 \\
\hline
\end{tabular}

Table 3. Bivariate Analysis of Quality of System.

\begin{tabular}{lc}
\hline \multicolumn{1}{c}{ Variables } & Results \\
\hline System user & \\
- Quality of system & $r=-0.054$ \\
- Spearman Correlation & $\mathrm{p}=0.585(>0.05)$ \\
\hline User Satisfaction & \\
- Quality of system & $r=0.060$ \\
- Spearman Correlation & $\mathrm{p}=0.541(>0.05)$ \\
\hline Organization & \\
- Quality of system & $r=-0.111$ \\
- Spearman Correlation & $\mathrm{p}=0.256(>0.05)$ \\
\hline Source: Primary data &
\end{tabular}

\section{Bivariate Analysis}

This study used a correlation hypothesis using the Spearmen test to look at the relationship between the independent variables and dependent variables.

Table 3 shows the significance value was greater than $0.05(0.585>0.05)$. It means that the quality of system was not related to system user. The information management system is a vital supportting tool for the hospital's operational management. Quick responses to services cause computer networks to be indispensable. A good computer network will have fast and integrated data flow which is also easily monitored. Besides, the test shows the quality of system had no relation with the system user due to server damage. The quality of system was poor because of limited system use (Munzir and Khaira, 2020). The system user by most users affects the quality of the system which naturally affects the users (Saputra, 2016). The perception of good quality will increase the user's enthusiasm to use the system. On the other hand, poor quality system will decrease the frequency of use. McGill et al. (2013) supports this assumption by saing that that improved perceptions of the quality systemmay affect users to use the system.

The bivariate analysis also shows that the quality of the system had no relation with the user satisfaction with the significance value greater than 0.05 $(0.541>0.05)$. Soraya et al. (2019) asserts the users might gain the benefits of using better quality system. The improvement of information system and the stability of service providers will increase the frequency of system use which leads to improved user satisfaction (Poluan, Lumenta and Sinsuw, 2015). User satisfaction reflects how far users believe in an information system to meet their information needs. It was proven that the quality of system haaffected on user satisfaction (Saputra, 2016). If the system has technical difficulties, inadequate infrastructure and errors, it can reduce the level of user satisfaction (DeLone and McLean, 2003). 
Table 3 explains the quality of system was not related to the organization with the significance level of 0.05 $(0.256>0.05)$. This findings might be triggered by no regular network maintenance for either software or hardware (Mudiono and Hernawati, Sri. Bukhori, 2018). Contrastly, the quality of system had a positive effect on the organization (Agustina and Susilani, 2018). Saputra (2016) finds that the organization needs to prepare the human resources to adapt to problems that may occur in the information system app (Saputra, 2016). According to Agustina and Susilani (2018), the organization had a positive effect on benefits to improve the system of hospital to be significant and directly.

In its use, the users often complained about the information management system app at Sabang Hospital. It indicates that the user satisfaction with the app was still low. The hospital management should respond to the complaints and find alternatives to solve it. Larinse (2015) and Saputra (2016) find the quality of the system is not related to the user satisfaction. Good user satisfaction and system use do not indicate any problems in terms of human resource variables. Especially, human resources with a high level of education and work experience may perform a high level of motivation and productivity (Diantono and Winarno, 2018).

Table 4. Bivariate Analysis of Quality of Information.

\begin{tabular}{lc}
\hline \multicolumn{1}{c}{ Variables } & Results \\
\hline System user & \\
- Quality of information & $r=0.278$ \\
- Spearman Correlation & $p=0.004(<0.05)$ \\
\hline User Satisfaction & \\
- Quality of information & $r=0.545$ \\
- Spearman Correlation & $p=0.000(<0.05)$ \\
\hline Organization & \\
- Quality of information & $r=0.147$ \\
- Spearman Correlation & $p=0.132(>0.05)$ \\
\hline Source: Primary data &
\end{tabular}

The bivariate analysis in Table 4 explains that the quality of information was related to the system user with $\mathrm{P}$-value of
0.004 . The result shows that the quality of information had a positive effect on the system use. In other words, the better the quality of information, the higher the frequency of the system use (Soraya, Adawiyah and Sutrisna, 2019). Simialrly, (Nurlani and Permana, 2017) discover that the quality of information affected the use of the information system significantly.

Moreover, the level of accuracy and relevance of information data become the aspects that determine the quality of information (Yusof et al., 2008). The accuracy of information is free from errors and unbiased. Meanwhile, the relevance of the information measures the benefits for the system users (Saputra, 2016). The relevance of information for each person varies. In other words, the quality of information is relatively based on the users' needs. When it meets the needs, it may be able to attract users to use the system. The respondents agreed that the quality of information was good, and thus the use of the system was relatively optimal.

The results show the quality of information contributed more to the use of the application compared to the quality of the application and the quality of the service. Besides, it is necessary to improve the quality of the system to produce good quality information for the users (Soraya, Adawiyah and Sutrisna, 2019). The quality of information by far had a relationship with the user satisfaction $(P$-value $=0.000)$. This finding is in line with the research (Soraya, Adawiyah and Sutrisna, 2019) who find the quality of information could affect the user satisfaction.

Meanwhile, the quality of information had no relationship with the organization (P-value=0.132). In another study, the quality of information was also determined the organizational control consecutively(Erimalata, 2016). Good and responsible organizations can support the quality of information in the system.

Bayu and Izzati (2013) assert user satisfaction can improve if the system is good and precise with the its quality of technology. (Krisbiantoro, Suyanto and Taufiqluthfi, 2015) state user satisfaction 
had a positive and significant effect on the use of the system.

The information management system app provided by Sabang Hospital processes and integrates the entire flow of healthcare management processes through coordinated networks, reports and administrative procedures to obtain precise and accurate information quickly. Higher level of satisfaction suggests that a hospital has better quality performance and employees (Saputra, 2016).

Table 5. Bivariate Analysis of Quality of Care

\begin{tabular}{lc}
\hline \multicolumn{1}{c}{ Variables } & Results \\
\hline System user & \\
- Quality of care & $r=0.452$ \\
- Spearman Correlation & $p=0.004(<0.05)$ \\
\hline User Satisfaction & \\
- Quality of care & $r=0.375$ \\
- Spearman Correlation & $p=0.000(<0.05)$ \\
\hline Organization & \\
- Quality of care & $r=0.360$ \\
- Spearman Correlation & $p=0.000(>0.05)$ \\
\hline Source: Primary data &
\end{tabular}

The result also shows there was a relationship between the quality of care and system user with P-value of 0.000 . Another study also finds similar result that the service quality had a positive effect on the system user. When the system user has good qualities, the service quality will be better (Soraya, Adawiyah and Sutrisna, 2019).

This study also reveals that the quality of care had a relationship with the user satisfaction. Another previous study supports this finding as it finds that the quality of care had a significant positive effect on user satisfaction (Erlirianto et al., 2015). Some factors that affect the quality of care are response speed, assurance, empathy and continued service, and the user satisfaction is a measure of perceived benefits and user attitudes towards an information system (Ayuardini and Ridwan, 2019).

In the same way, the quality of care was related to organization with the $P$-value of 0.00 . Another study argues that the quality of care affected an organization where the support of top management and staff are the aspects of measuring a system (Soraya, Adawiyah and Sutrisna, 2019). According to (Habiburrahman, 2016), leadership of the top management support and staff also supports the success of system implementation. Besides, established policies or rules by the hospital management may push the quality of service and care much better.

The implementation of information system requires to measure the quality of the information system which can give hints on the quality of service and user satisfaction (Saputra, 2016). In achieving this target, the hospital management needs to handle complaints quickly to improve the user satisfaction (Nofikasari and Sunyoto, 2017). This study further uncovers that the quality of information system services was poor and had the most influence on user satisfaction. Therefore, the hospital should prioritize the quality of service to improve user satisfaction (Saputra, 2016).

The successful implementation of information management system app is measured from three components: technology, human and organization. The information management system app measures its technological component from the quality of its system, information, and frequency of use It also has something to do with the human component which is assessed from the use of the system and user satisfaction. Each aspect of the technology component affects the use of system and organization (Soraya, Adawiyah and Sutrisna, 2019). The organizational component will determine the use of the system which affects user satisfaction later on. In summary, the use of the system, user satisfaction, and organizational control will affect the implementation of information management system app (Habiburrahman, 2016).

\section{CONCLUSION}

The information management system integrates information to support the organizational operation, management and decision-making functions. It is an output of information system to meet certain objectives in managerial activities. 
The quality of information management system is measure from the quality of information and types of services offered. This system helps provide information about patient's care and administration requirements during its admission to the hospital in a relevant manner. Data in the system will be collected, stored, processed, and documented to generate information about the quality of patient care and hospital performance and service costs.

This study recommends the hospital needs to improve the quality of the system to encourage users use the system more frequently. Besides, the hospital needs to provide infrastructure for the operation of hospital information management system. Therefore, the policy makers should support to reduce problems in its operation. It is necessary to conduct training on the hospital information management system app to educate the staff to operate it well.

Regarding the app development, companies should develop the app features to make the system more attractive and easier for data recapitulation. This study highlights some limitations. For instance, the researchers in this study used an individual questionnaire to collect data. Therefore, the validity of findings between variables depends on the subjectivity of the respondents in filling the questionnaire. Finally, further research can identify the effect of variables which have not been investigated yet in the HOT Fit method or other methods.

\section{CONFLICT OF INTEREST}

There is no conflict of interest in this study.

\section{REFERENCES}

Agustina, R. and Susilani, A. T. (2018) 'Evaluasi Sistem Informasi Manajemen Rumah Sakit (SIMRS) pada Bagian Pendaftaran Rawat Jalan dengan Metode HOT-FIT', Prosiding Seminar Nasional Multimedia \& Arttficial Intelligence,
8(4), pp. 75-80.

Alotaibi, Y. K. and Federico, F. (2017) 'The impact of health information technology on patient safety', Saudi Medical Journal. doi: 10.15537/smj.2017.12.20631.

Ayuardini, M. and Ridwan, A. (2019) 'Implementasi Metode Hot Fit pada Evaluasi Tingkat Kesuksesan Sistem Pengisian KRS Terkomputerisasi', Faktor Exacta, 12(2), pp. 122-131. doi: 10.30998/faktorexacta.v12i2.3639.

Buntin, M. B. et al. (2011) 'The benefits of health information technology: A review of the recent literature shows predominantly positive results', Health Affairs. doi: 10.1377/hlthaff.2011.0178.

Chaudhry, B. et al. (2006) 'Systematic review: Impact of health information technology on quality, efficiency, and costs of medical care', Annals of Internal Medicine. doi: 10.7326/0003-4819-144-10$200605160-00125$.

Cheung, T. and Yip, P. S. F. (2017) 'Workplace violence towards nurses in Hong Kong: prevalence and correlates'. BMC Public Health, pp. 1-10. doi: 10.1186/s12889-0174112-3.

Dahlan, M. (2017) Statistik Untuk Kedokteran Dan Kesehatan. Jakarta: Epidemiologi Indonesia.

DeLone, W. H. and McLean, E. R. (2003) 'The DeLone and McLean model of information systems success: A tenyear update', Journal of Management Information Systems, 19(4), pp. 9-30. doi: 10.1080/07421222.2003.11045748.

Diantono, P. and Winarno, W. W. (2018) 'Evaluasi Penerapan SIMRS Menggunakan Metode Hot-Fit Di RSUD Dr . Soedirman Kebumen', Jurnal IImiah Penelitian dan Penerapan Teknologi Sistem Informasi, 2(1), pp. 46-56. doi: 10.29407/ intensif.v2i1.11817.

El-Kareh, R., Hasan, O. and Schiff, G. D. (2013) 'Use of health information technology to reduce diagnostic errors', BMJ Quality and Safety. doi: 
10.1136/bmjqs-2013-001884.

Erimalata, S. (2016) 'Pendekatan Hot-Fit Framework dalam Generalized Structural Component Analysis pada Sistem Informasi Manajemen Barang Milik Daerah: Sebuah Pengujian Efek Resiprokal', Journal of Accounting and Investment, 17(2), pp. 141-157. doi: 10.18196/jai.2016.0051.

Erlirianto, L. M. et al. (2015) 'The Implementation of the Human , Organization, and Technology - Fit (HOT - Fit) Framework to evaluate the Electronic Medical Record (EMR) System in a Hospital', Procedia Computer Science. Elsevier Masson SAS, 72(7), pp. 580-587. doi: 10.1016/j.procs.2015.12.166.

Farzandipou, M. et al. (2017) 'Evaluation of Key Capabilities for Hospital Information System: A Milestone for Meaningfull Use of Information Technology', Annals of Tropical Medicine and Public Health, 10(6), pp. 1579-1586. doi: 10.30829/jipi.v1i1.111.

Habiburrahman (2016) 'Model-Model Evaluasi Dalam Sistem Informasi Perpustakaan', IImu Perpustakaan Dan Informasi. doi: 10.30829/jipi.v1i1.111.

Ingebrigtsen, T. et al. (2014) 'The impact of clinical leadership on health information technology adoption: Systematic review', International Journal of Medical Informatics. doi: 10.1016/j.ijmedinf.2014.02.005.

Krisbiantoro, D., Suyanto, M. and Taufiqluthfi, E. (2015) 'Evaluasi Keberhasilan Implementasi Sistem Informasi Dengan Pendekatan HOT FIT Model (Studi Kasus: Perpustakaan STMIK AMIKOM Purwokerto)', 4(2), pp. 896-901.

Lee, J., Mccullough, J. S. and Town, R. J. (2013) 'The impact of health information technology on hospital productivity', RAND Journal of Economics. doi: 10.1111/17562171.12030.

Lintonen, T. P., Konu, A. I. and Seedhouse, D. (2008) 'Information technology in health promotion', Health Education Research. doi: 10.1093/her/cym001.

Moore, C. R. (2018) 'Health information technology', in Chronic Illness Care: Principles and Practice. doi: 10.1007/978-3-319-71812-5_34.

Mudiono, D. and Hernawati, Sri. Bukhori, S. (2018) 'Dampak Kualitas Sistem, Pengguna Sistem dan Organisasi dalam Pemanfaatan Kinerja Sistem Informasi Manajemen Rumah Sakit di RSU Dr. H. Koesnadi', Journal Unej, 589(1), pp. 25-29. doi: 10.19184/multijournal.v1i1.8594.

Munzir, M. and Khaira, N. (2020) 'Evaluasi Keberhasilan Implementasi Sistem Informasi Manajemen Kuliah Kerja Nyata Menggunakan Metode Hot Fit', Ilmiah Rekayasa dan Manajemen Sistem Informasi, 6(1), pp. 100-108.

Nguyen, L., Bellucci, E. and Nguyen, L. T. (2014) 'Electronic health records implementation: An evaluation of information system impact and contingency factors', International Journal of Medical Informatics. doi: 10.1016/j.jimedinf.2014.06.011.

NHS England (2016) Making it work: harnessing the power of health information technology to improve care in England, Making IT Work.

Nofikasari, I. and Sunyoto, A. (2017) 'Evaluasi Penerapan Sistem Informasi Akademik Dengan Pendekatan Model Delone \& McLean, HOT FIT dan UTAUT (Studi Kasus: STMIK Duta Bangsa Surakarta)', 12(1), pp. 81-90.

Nurlani, L. and Permana, B. (2017) 'Analisa Kesuksesan Sistem Informasi Akademik Menggunakan Model Terintegrasi', 2(2), pp. 105116. doi: 10.31544/jtera.v2.i2.2017. 105-116.

Pamugar, H., Winarno, W. W. and Najib, W. (2014) 'Model Evaluasi Kesuksesan dan Penerimaan Sistem Informasi E- Learning pada Lembaga Diklat Pemerintah', Scientific Journal of Informatics, 1(1), pp. 13-28. doi: 10.15294/sji.v1i1. 3638. 
Poluan, F., Lumenta, A. and Sinsuw, A. (2015) 'Evaluasi Implementasi Sistem E-Learning Menggunakan Model Evaluasi Hot Fit Studi Kasus Universitas Sam Ratulangi', Jurnal Teknik Informatika, 4(2), pp. 1-6. doi: 10.35793/jti.4.2.2014.6985.

Rusdiana, H. A. (2014) Sistem Informasi Manajemen. Bandung: Cv. Pustaka Setia.

Saputra, A. B. (2016) 'Identifikas FaktorFaktor Keberhasilan Implementasi Sistem Informasi Manajemen Rumah Sakit', Jurnal Penelitian Pers dan Komunikasi Pembangunan, 19(3), pp. 135-148.

Shekelle, P. G., Morton, S. C. and Keeler, E. B. (2006) 'Costs and benefits of health information technology.', Evidence report/technology assessment. doi: 10.23970/ahrqepcerta132.

Soraya, I., Adawiyah, W. R. and Sutrisna, E. (2019) 'Pengujian Model Hot Fit Pada Sistem Informasi Manajemen Obat di Instalasi Farmasi RSGMP Unsoed Purwokerto', Jurnal Ekonomi, Bisnis, dan Akuntansi, 21(1), pp. 1-16.

Sudiarti, T., Soepangat, S. and Wiyono, T. (2019) 'Analisis Implementasi Sistem Informasi Manajemen di Instalasi Rawat Jalan Klinik Paru Analysis of Implementation of Management Information System', 5(1), pp. 57-67. 